\title{
Borderline radiocarbon
}

\section{J. van der Plicht}

Center for Isotope Research, University of Groningen; also at Faculty of Archaeology, Leiden University. Email: j.van.der.plicht@rug.nl.

Manuscript received: July 2011, accepted: November 2011

\begin{abstract}
Radiocarbon dating of peat has its intrinsic problems. This is often caused by mobile organic fractions. For the Weichselian Pleniglacial, another methodological problem arises: the limit of the ${ }^{14} \mathrm{C}$ dating method. This is discussed in terms of bulk (i.e. non-selected material, generally dated conventionally) vs AMS (i.e. selected botanical remains) dates, contamination, background and calibration, guided by a series of peat samples from the Belgian/Dutch border.
\end{abstract}

\section{Introduction}

The radiocarbon dating method was developed around 1950 by W.F. Libby (1908-1980), who received the Nobel Prize in chemistry for this important discovery in 1960 (Libby, 1952; Berger, 1983). The method became a main chronological measuring tool in disciplines like Archaeology and Quaternary Earth Sciences. Organic matter, from fossil bone to plant remains, can be directly dated by a physical measurement.

At the University of Groningen, soon after the proof of principle by Libby, the archaeologist A.E. van Giffen instigated the physicist $\mathrm{H}$. De Vries to build a ${ }^{14} \mathrm{C}$ detector. This marks the start of the Groningen ${ }^{14} \mathrm{C}$ laboratory. As is well known, De Vries made crucial contributions to the development of the ${ }^{14} \mathrm{C}$ dating method.

Apart from the most widely known application of ${ }^{14} \mathrm{C}$ dating, archaeology, there is also a long standing tradition in Quaternary Geology. In the Netherlands this traditional cooperation started soon after the establishment of the laboratory in Groningen, with the Quaternary scientists of both the Vrije Universiteit in Amsterdam (VU; A.L. Wiggers and W. Roeleveld) and the State Geological Survey in Haarlem (RGD; W.H. Zagwijn). Historically, it started with sea level research, for which ${ }^{14} \mathrm{C}$ dates are an essential input. Large series of peat samples from the coastal region were dated for the construction of sea level curves (Jelgersma, 1961).
In 1976, Jef Vandenberghe joined the staff of the VU, and continued the intensive relations with the Groningen laboratory. His first ${ }^{14} \mathrm{C}$ date was GrN-7860 for Vijve-Kapelle near Brugge (reported in letter dated 20-01-1978 by W.G. Mook). Not only did he cross the border between Belgium and Netherlands at some point in time; on behalf of the VU, he also crossed the border of the Holocene-Pleistocene, at least concerning research where ${ }^{14} \mathrm{C}$ dates are needed. Quite often this also meant that samples became borderline: Weichselian Pleniglacial deposits easily lack organic material, both in terms of quantity (even for AMS in some cases) and quality, from the ${ }^{14} \mathrm{C}$ point of view that is.

Peat is an example of organic deposits which are datable by ${ }^{14} \mathrm{C}$. Unfortunately, peat samples have their own specific problems: not the measurement, but the inference of correct ages (e.g., Shore et al., 1995). This problem is amplified for the Pleniglacial, where another (this time unsurmountable) border is reached: the age limit of the ${ }^{14} \mathrm{C}$ dating method. This limit is around 50,000 years, somewhat depending on detection technique and sample quality. Beyond this limit, the remaining amount of ${ }^{14} \mathrm{C}$ is too small to be measured. This will be illustrated by one of the first dating projects performed by Jef: peat from the border region between Belgium and the Netherlands (Vandenberghe, 1985). This project dates back to the 1980's. Following a short review of the ${ }^{14} \mathrm{C}$ method, more recent developments will be discussed, as the method keeps being refined, in particular towards the 50,000 years limit. Problems for proper age inference remain, however, also for peat. 


\section{Radiocarbon dating}

The radiocarbon dating method is based on the measurement of the concentration or the rate of decay of the radioactive isotope ${ }^{14} \mathrm{C}$. This isotope is continuously produced in the upper atmosphere through cosmic rays. Via photosynthesis it enters the biosphere and is present in minute quantities in plants, and also (via the foodchain) animals and humans. The original method, developed by Libby, is the so-called conventional method, based on radiometry. It involves large (bulk) gramsize samples and a low background gas counter setup. The samples need to be cleaned and a proper datable fraction isolated, which will be combusted in $\mathrm{CO}_{2}$ gas for the counters. An alternative radiometric method is liquid scintillation counting.

Organic ${ }^{14} \mathrm{C}$ samples, such as peat, are chemically pretreated with AAA, which is the usual chemical treatment for samples and stands for Acid/Alkali/Acid. The first step removes carbonates (contaminants) and fulvic acids; the second step removes humic acids; the final acid step removes any $\mathrm{CO}_{2}$ possibly adsorbed during the previous alkali step (Mook and Streurman, 1983).

Radiocarbon dating has improved dramatically since the early 1950's in all practical applications. The precision of the physical measurements improved by about an order of magnitude to $0.2-0.5 \%$, depending on available sample size and quality (e.g., De Jong et al., 1989). Mass dependent effects (isotope fractionation) influence the ${ }^{14} \mathrm{C}$ content of samples, and thus their ${ }^{14} \mathrm{C}$ age. These effects became understood and can be corrected for using the content of the stable isotope ${ }^{13} \mathrm{C}$ in the ${ }^{14} \mathrm{C}$-dated sample (e.g., Mook and Streurman, 1983).

Mutual experience of both ${ }^{14} \mathrm{C}$ scientists and scientists from the user communities led to practical recommendations for sample selection criteria (Mook \& Van de Plassche, 1986; for a more recent update see Van Strydonck et al., 1999).

Past variations in the natural ${ }^{14} \mathrm{C}$ concentration, discovered by De Vries (1958) caused another problem. This causes radiocarbon years to be different (and varying) from calendar years. This difficulty was solved by defining the radiocarbon timescale. By convention, the measurements are related to a standard radioactivity; ages are calculated using a conventional halflife value; and isotope fractionation is corrected to a standard value. The radiocarbon dates are expressed in the unit BP. This originally meant 'Before Present' with Present being 1950 AD (e.g., Mook \& Van de Plassche, 1986). But since the Radiocarbon timescale appears to be elastic, this can not be taken literally. We now know that $10,000{ }^{14} \mathrm{C}$ years ago (BP) corresponds with roughly $10,000 \mathrm{BC}$ or 12,000 calendar years ago. As a consequence, radiocarbon dates need to be calibrated into calendar years, only then the method can be considered 'absolute' (e.g., Van der Plicht \& Mook, 1989). Calibration thus connects the defined ${ }^{14} \mathrm{C}$ timescale (BP) with the calendar. It automatically takes into account both the wrong conventional halflife, and the varying natural ${ }^{14} \mathrm{C}$ content. A milestone in this 'revolution in dating' (Renfrew, 1999) was the publication of the first recommended calibration curves, based on both dendrochronologically and ${ }^{14} \mathrm{C}$ dated tree ring series from the United States, Ireland and Germany (Stuiver \& Pearson, 1986; Pearson \& Stuiver, 1986).

Only recently, calibration curves became available covering the complete Radiocarbon dating range of 50,000 years (Reimer et al., 2009). This calibration curve intcal09 is shown in Fig. 1. It is based on dendrochronologically dated wood back to 12,500 years ago; the older part of the curve is derived from selected marine samples: U-series dated corals and foraminifera. For selection criteria, see Reimer et al. (2002). The ${ }^{14} \mathrm{C}$ ages are reported in BP (the marine data being corrected for the so-called reservoir effect), and the calendar timescale is plotted in calBP. This is defined as absolute years relative to the year $1950 \mathrm{AD}$, i.e. calBP $=1950-\mathrm{AD}$ or equivalently calBP $=$ 1950+BC (Mook \& Van der Plicht, 1999). Note that this use of calBP (and BP) is specific for the ${ }^{14} \mathrm{C}$ community. In earth sciences and other disciplines, the meaning of these terms can be different, which easily leads to confusion and/or errors.

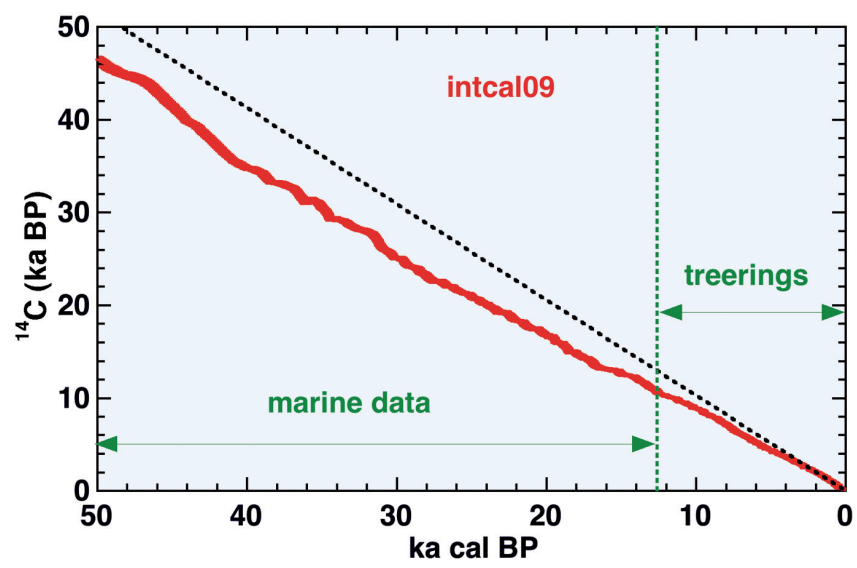

Fig. 1. The calibration curve Intcal09 for the Radiocarbon timescale (Reimer et al., 2009). The blue dotted line represents the 1:1 line, i.e. the hypothetical case where ${ }^{14} \mathrm{C}$ time and calendar time are the same.

The marine reservoir effect is caused by the different ${ }^{14} \mathrm{C}$ concentrations in the terrestrial/atmospheric reservoir, and the surface ocean. Because of the upwelling of deep and old water, the surface ocean contains less ${ }^{14} \mathrm{C}$ and thus shows an apparent age. Today, this is an offset of 400 years in and around the Northern Atlantic 0cean; however, it may show different values depending on location. Also in the past, oceanic reorganisations during glacial periods may have resulted in different reservoir ages. This causes uncertainties in the exact course of the calibration curve. The general picture will probably not change dramatically at the scale shown in Fig. 1. A calibration curve based on truly terrestrial samples is not yet available. Glacial tree ring records do exist, most particular for Kauri wood (Balter, 2006). But as of today, there is no dendrochronological anchor point available for these trees. 
One should be careful with terms like 'revolution', but it has been assigned to another ${ }^{14} \mathrm{C}$ development as well: the advent and implementation of AMS. This latter method enables dating of small (milligram size) samples such as single seeds, pollen, macrofossils, foraminifera, wood from annual tree rings, and precious bones and artefacts (Mook, 1984; Tuniz et al., 1998). For samples like peat, this small sample capability meant a move from bulk (i.e. non-selected material, generally dated conventionally) samples to selected botanical remains (which can only be dated by AMS because of sample size). In Groningen, Accelerator Mass Spectrometry became operational in 1994. It is based on a 2.5 MV particle accelerator. For a description including technical details, see Van der Plicht et al. (2000) and references therein.

\section{Peat dating}

A selection of peat samples, submitted by Jef Vandenberghe to the Groningen laboratory around 1980, is shown in Table 1. They are all conventional dates (laboratory code GrN), thus bulk peat samples, before AMS was introduced. All samples come from the Belgian/Dutch border.

Apart from sample description and lithostratigraphical position, the table shows the chemical treatment, dated fraction, ${ }^{14} \mathrm{C}$ age and the 'quality parameters' ${ }^{13} \delta$ (the stable isotope ${ }^{13} \mathrm{C} /{ }^{12} \mathrm{C}$ with respect to a standard) and $\mathrm{C}_{\mathrm{V}}$ (the Carbon content).

The usual values for peat are ${ }^{13} \delta \approx-27 \%$, and $C_{\mathrm{V}}$ ranges from 45 to 55\% (Mook \& Streurman, 1983; Mook \& Van de Plassche, 1986). Most of the sites are paleo-environmentally described in Vandenberghe, 1985 . Here we only discuss the ${ }^{14} \mathrm{C}$ related methodological issues. The oldest ages, according to expectations based on lithostratigraphy, are 'End Eemian/Early Weichselian', i.e. 50-75 $\mathrm{ka}$ as corresponding dates at that time. The main general observation is that the majority of the dates seem to be younger than expected. There are two major aspects of such dates that need to be discussed in this respect: background and contamination. First and most relevant is the question of the background. In ${ }^{14} \mathrm{C}$ practice, background samples are anthracite, i.e. so old that it does not contain ${ }^{14} \mathrm{C}$. Nevertheless, the measurements of such samples show ${ }^{14} \mathrm{C}$ registrations which are produced by contamination that is either introduced during sample handling or was present in the sample and could not be removed by sample treatment, by foreign radioactivity which is not adequately shielded, etc. The age measured for anthracite (infinite age material) is the background, and in practice for the conventional laboratory this is $50-55,000 \mathrm{BP}$. The caveat is (in a way) obvious but not always recognised: anthracite does not behave the same as peat in this respect. For a peat date, the anthracite (i.e. infinitely old charcoal) is subtracted, and not infinitely old peat. Eemian peat is infinitely old, on the ${ }^{14} \mathrm{C}$ timescale. Thus, if peat samples are contaminated by mobile younger fractions, they easily can show finite ages. Such 'mobile carbon' contamination does not happen with anthracite, or samples like charcoal or nondegraded wood.

Similar problems exist in archaeology for dates of fossil bone near the ${ }^{14} \mathrm{C}$ detection limit. Here collagen is the extracted datable fraction, and as background also anthracite is used, and not infinitely old bone. Bone collagen dates close to the ${ }^{14} \mathrm{C}$ detection limit should always be regarded with caution, despite

Table 1. Radiocarbon dates for bulk peat samples (except GrN-8941 which is wood), discussed in the text. The ${ }^{14} \mathrm{C}$ dates are calibrated using Intcal09 (Reimer et al., 2009), and are reported in calBP (calendar ages relative to 1950 AD).

\begin{tabular}{|c|c|c|c|c|c|c|c|c|c|}
\hline GrN nr. & Sample & Treatment & Dated fraction & ${ }^{14} \mathrm{C}$ age $\mathrm{BP}$ & Error 10 & ${ }^{13} \delta \%$ & Age calBP & $\mathrm{C}_{\mathrm{v}} \%$ & Expected age \\
\hline 9720 & Riel 2A & AAA & residue & 48400 & $+3200,-2300$ & -29.13 & $>50000$ & 49 & Eemian/Early Weichselian \\
\hline 10187 & idem & & alkali & 51000 & $+4000,-2600$ & -28.15 & $>50000$ & 54 & \\
\hline 8944 & Tilburg 2 & AAA & residue & 40850 & 750 & -28.55 & $44120-45160$ & 58 & Eemian/Early Weichselian \\
\hline 10333 & idem & & alkali & 31140 & 310 & -29.15 & $35180-36370$ & 48 & \\
\hline 8935 & Ravels $1 \mathrm{~A}$ & AAA & residue & 31560 & 320 & -29.11 & $35510-36510$ & 45 & Early Weichselian \\
\hline 10331 & idem & & alkali & 28000 & 750 & -28.73 & $31490-33090$ & & \\
\hline 8936 & Ravels 2 & AAA & residue & 36150 & 550 & -28.11 & $40880-41750$ & & Early Weichselian \\
\hline 10186 & idem & & alkali & 28600 & 210 & -27.99 & $32810-33300$ & & \\
\hline 8937 & Ravels 3 & AAA & residue & 10420 & 50 & -27.63 & $12150-12410$ & & Middle Weichselian \\
\hline 10332 & idem & & alkali & 9780 & 50 & -27.99 & $11190-11240$ & & \\
\hline 8940 & Turnhout 22 & AAA & residue & 29280 & 280 & -28.50 & $33660-34460$ & 66 & Early Weichselian \\
\hline 8941 & Turnhout 23 & AAA & residue (wood) & $>53000$ & & -28.04 & $>50000$ & 65 & Early Weichselian \\
\hline 8410 & Turnhout 1 & $\mathrm{~A}$ & residue & 38500 & 1200 & -28.18 & $42100-43820$ & & Middle Weichselian \\
\hline 8403 & Turnhout 13 & $\mathrm{~A}$ & residue & 11800 & 230 & -27.95 & $13410-13860$ & & Middle Weichselian \\
\hline 9527 & Poppel & AAA & residue & 8050 & 60 & -27.95 & $8780-9030$ & 38 & $20-50000 \mathrm{BP}$ \\
\hline 10283 & idem & & alkali & 7650 & 100 & -28.01 & $8380-8540$ & 50 & \\
\hline 10282 & idem & & roots & 2420 & 190 & -27.03 & $2320-2750$ & 0.3 & \\
\hline
\end{tabular}


new cleaning techniques introduced (Bronk Ramsey et al., 2004). Also some marine shell species show this problem. They can show open system behaviour. It is well known that Eemian (and even older) shells can show ${ }^{14} \mathrm{C}$ ages of 30,000 BP. Carbonates often show 'multiple personalities', as is discussed by Nadeau et al. (2001). In practice, it is not possible to use ${ }^{14} \mathrm{C}$-infinite bone for bone dating, or ${ }^{14} \mathrm{C}$-infinite peat for peat dating, using proper materials truly representating blanks for the samples to be dated. For samples near the dating limit this can be leading to problematic dates.

The ${ }^{14} \mathrm{C}$ measurements proper are almost always correct; if a ${ }^{14} \mathrm{C}$-infinite sample is measured as finite, it is usually caused by allochtonous ${ }^{14} \mathrm{C}$. One should also keep in mind that only relatively few ${ }^{14} \mathrm{C}$ atoms are enough to make an infinite $(>50,000 \mathrm{BP})$ sample finite $(<50,000 \mathrm{BP})$. To mention an example, a 50,000 year old peat sample which is contaminated with $1 \%$ modern material, produces a date of ca 35,000 BP. Graphs showing this effect for various amounts of contamination can be found in handbooks and publications like Mook and Van de Plassche (1986).

It is possible to move the dating limit back in time to $60-70$ ka by enrichment. For large size (kilograms!) peat samples this has been shown possible by Grootes (1977) for the conventional ${ }^{14} \mathrm{C}$ method. At present, enrichment is tested for AMS (Meijer et al., forthcoming). Despite the proof that it can be made to work, it should be noted that enrichment is not suitable for dating applications in practice, since it is a very time consuming and expensive laboratory process.

In this respect, well preserved wood is more representative than peat which is more open and subject to moving organic fractions. The table shows one wood sample (Turnhout, GrN-8941) from the Early Weichsel, which is dated to $>53,000 \mathrm{BP}$, i.e. infinite on the ${ }^{14} \mathrm{C}$ scale. The Early Weichsel peat samples show finite ages. For radiocarbon ages close to the background, the measurement errors become asymmetric. This is the case for a few samples (Table 1) like Riel 2A. For the convention dealing with such errors see Van der Plicht \& Hogg (2006).

Second, but not less important, proper pretreatment of samples is essential to remove contaminants and isolate the correct datable fraction. Contaminants (i.e. materials containing allochtonous Carbon) are usually movable fractions, possibly introducing $C$ from various sources. Also long-term storage of samples can introduce contamintion, caused by fungi or microorganisms (Wohlfarth et al., 1998).

Based on their solubilities, the organic compounds are subdivided in fulvic acids (soluble in alkaline and in acids) and humic acids (soluble in alkaline, precipitating in acids). A residual fraction (often referred to as humin) is insoluble in both acids and alkaline. The latter organic molecules, originating from the decomposition of organic matter, are relatively resistent against further degradation. This is considered the actual autogenous organic matter. Therefore, this residual fraction (humin) is used for ${ }^{14} \mathrm{C}$ dating. The fulvic acids represent a very instable phase of humic components, which is highly mobile and move relatively quickly through a profile. Since in general there is net water transport downwards, this means that they generally show a younger age than the other fractions at the same depth.

Organic ${ }^{14} \mathrm{C}$ samples, such as peat, are chemically pretreated with AAA (see above). When possible, dating of several fractions can be used to check for dating homogeneity of the sample material. Generally, a consistent date for both residual and alkaline fractions is a quality check for the homogeneity of the sample. This is then considered as a good indication of the relative integrity of the material selected for dating. The younger alkaline extract generally contains the infiltrated humic substances, whereas the older residue supposedly consists of the actual autogenous organic matter.

Most samples shown in the table underwent full chemical pretreatment (AAA). The residue is the 'normal' datable fraction (see above); the alkali fraction has been dated as well for selected samples. The alkali dates are all younger than the residue dates. The largest difference is observed for Tilburg 2; this difference is close to 9,000 years. Riel $2 \mathrm{~A}$ is the oldest sample. Both residue and alkali fractions yield the same age, within errors which are large. The measured ages are dangerously close to the dating limit. Some samples were too delicate or too small for complete treatment; they only underwent the first acid step (A-only treatment). The danger is then that the date can be too young, as is indeed the case for Turnhout 13; this Early Weichsel sample yields 11,800 BP. Apparently, there was no complete removal of the humic acids.

\section{Final remarks}

Bulk peat sample dating was the only possibility during the conventional era. The introduction of AMS enabled ${ }^{14} \mathrm{C}$ dating of small samples, which for peat can be translated into selected macrofossils or seeds (Blaauw, 2003 and references therein). That solved dating problems caused by mobile organic fractions, and the consensus that Sphagnum plant fragments should be used in ${ }^{14} \mathrm{C}$ dating of peat (e.g., Nilsson et al., 2001). It would be useful to revisit some of the Belgian/Dutch borderline bulk peat samples and date selected fractions.

An example is the dating of selected seeds from another borderline (in terms of ${ }^{14} \mathrm{C}$ age) sequence from Wageningen. Here consistent dates between 40 and 60,000 years were obtained, the youngest one by ${ }^{14} \mathrm{C}$, and the older ones by OSL dating (Van Geel et al., 2010). More intercomparisons between ${ }^{14} \mathrm{C}$ and OSL dating of such sequences are underway (Van der Plicht \& Wallinga, in preparation).

Contaminants become more important when the sample is older. These contaminants are usually modern materials, making the samples date too young when not adequately removed. For example, a 50,000 year old sample will be measured as 35,000 BP, when there is $1 \%$ modern contamination. For AMS, this effect 
is more problematic than for the conventional method because of the intrinsically small samples (by a factor of 1000) that are used. Examples are given by Lanting \& Van der Plicht (1993/ 1994).

In his lecture at the symposium on the occasion of his retirement, Jef Vandenberghe explained that one of the main principles of Geology is that rivers tend to flow from higher to lower elevations. For peat deposits, the analogon is that mobile organic fractions tend to move from high to low, i.e. from younger to older layers. In Physics there is a similar principle: radioactive isotopes like ${ }^{14} \mathrm{C}$ decay from a higher concentration to a lower one. These two great principles in science meet in the Weichselian Pleniglacial. Borderline radiocarbon samples are close to the dating limit, sensitive to contamination by foreign carbon, and often constitute a lack of well defined organic material. Since the era of dating bulk samples of organic deposits and peat, a lot of progress has been made: AMS enabling dating of selected plant remains, calibration of the full ${ }^{14} \mathrm{C}$ dating range, and combined ${ }^{14} \mathrm{C} / 0 \mathrm{SL}$ efforts are making progress towards good chronologies. But puzzles remain to be solved.

\section{References}

Balter, M., 2006. Radiocarbon dating's final frontier. Science 313: 1560-1563. Berger, $\boldsymbol{R} ., 1983$. Willard Frank Libby, 1908-1980. PACT publications 8: 13-16. Blaauw, M., 2003. An investigation of Holocene sun-climate relationships using numerical ${ }^{14} \mathrm{C}$ wiggle match dating of peat deposits. PhD Thesis, University of Amsterdam.

Bronk Ramsey, C., Higham, T., Bowles, A. \& Hedges, R., 2004. Improvements to the pretreatment of bone at 0xford. Radiocarbon 46: 155-163.

De Jong, A.F.M., Mook, W.G., \& Becker, B., 1989. Corrected calibration of the Radiocarbon timescale: 390-3203 calBC. Radiocarbon 31: 201-210.

De Vries, H., 1958. Variation in concentration of Radiocarbon with time and location on earth. KNAW Proceedings B61:1-9.

Grootes P.M., 1977. Thermal diffusion isotopic enrichment and radiocarbon dating beyond 50,000 years BP. PhD thesis, University of Groningen.

Jelgersma, S., 1961. Holocene Sea Level Changes in the Netherlands. Thesis Leiden University, Mededelingen Geologische Stichting, CVI-7.

Lanting, J.N. \& Van der Plicht, J., 1993/1994. ${ }^{14}$ C-AMS: pros and cons for Archaeology. Palaeohistoria 35/36: 1-12.

Libby, W.F., 1952. Radiocarbon dating. University Press, Chigaco. re-issued 1965.

Mook, W.G., 1984. Archaeological and geological interest in applying ${ }^{14} \mathrm{C}$ AMS to small samples. Nuclear Instruments and Methods B5: 297-302.

Mook, W.G. \& Streurman, H.J., 1983. Physical and chemical aspects of radiocarbon dating. PACT Publications 8: 31-55.

Mook, W.G., \& Van de Plassche, O., 1986. Radiocarbon dating. In: Van de Plassche, 0 . (ed.): Sea-level research: a manual for the collection and evaluation of data. Geobooks: 525-560.

Mook, W.G. \& Van der Plicht, J., 1999. Reporting ${ }^{14} \mathrm{C}$ activities and concentrations. Radiocarbon 41: 227-239.
Nadeau, M.J., Grootes, P.M., Voelker, A., Bruhn, F., Duhr, A. \& Oriwall, A., 2001. Carbonate ${ }^{14} \mathrm{C}$ background: does it have multiple personalities? Radiocarbon 43: 169-176.

Nilsson, M., Klarqvist, M., Bohlin, E. \& Possnert, G., 2001. Variation in ${ }^{14} \mathrm{C}$ age of macrofossils and different fractions of minute peat samples dated by AMS. Holocene 11: 579-586.

Pearson, G.W. \& Stuiver, M., 1986. High precision calibration of the Radiocarbon timescale, 500-2500 BC. Radiocarbon 28: 839-862.

Reimer, P.J., Hughen, K.A., Guilderson, T.P., McCormac, F.G., Baillie, M.G.L., Bard, E., Baratt, P., Beck, J.W., Brown, D.M., Buck, C.E., Damon, P.E., Friedrich, M., Kromer, B., Ramsey, C.B., Reimer, R.W., Remmele, S., Southon, J.R., Stuiver, M. \& Van der Plicht, J., 2002. Preliminary report of the first workshop of the Intcal04 Radiocarbon Calibration/Comparison Working Group. Radiocarbon 44: 653-661.

Reimer, P.J., Baillie, M.G.L., Bard, E., Bayliss, A., Beck, J.W., Blackwel, P.G., Bronk Ramsey, C., Buck, C.E., Burr, G.S., Edwards, R.L., Friedrich, M., Grootes, P.M., Guilderson, T.P., Hajdas, I., Heat, T.J., Hogg, A.G., Hughen, K.A., Kaiser, K.F., Kromer, B., McCormac, F.G., Manning, S.W., Reimer, R.W., Richards, D.A., Southon, J.R., Talamo, S., Turney, C.S.M., Van der Plicht, J. \& Weyhenmeyer, C.E., 2009. IntCal09 and Marine09 radiocarbon age calibration curves, 0-50,000 years cal BP. Radiocarbon 51: 1111-1150.

Renfrew, C., 1999. Before civilisation: the Radiocarbon revolution and Prehistoric Europe. Pimlico, London.

Shore, J.S., Bartley, D.D. \& Harkness, D.D., 1995. Problems encountered with the ${ }^{14} \mathrm{C}$ dating of peat. Quaternary Science Reviews 14: 373-383.

Stuiver, M. \& Pearson, G.W., 1986. High precision calibration of the Radiocarbon timescale, AD 1950-500 BC. Radiocarbon 28: 805-838.

Tuniz, C., Bird, J.R., Fink, D. \& Herzog, G.F., 1998. Accelerator Mass Spectrometry: ultrasensitive analysis for global science. CRC Press, Boca Raton.

Vandenberghe, J., 1985. Paleoenvironment and stratigraphy during the Last Glacial in the Belgian-Dutch border region. Quaternary Research 24: 23-38.

Van der Plicht, J. \& Mook, W.G., 1989. Calibration of Radiocarbon ages by computer. Radiocarbon 31: 805-816.

Van der Plicht, J., Wijma, S., Aerts, A.T., Pertuisot, M.H. \& Meijer, H.A.J., 2000. The Groningen AMS facility: status report. Nuclear Instruments and Methods B172: 58-65.

Van der Plicht, J. \& Hogg, A., 2006. A note on reporting Radiocarbon. Quaternary Geochronology 1: 237-240.

Van Geel, B., Bos, H.H., Pals, J.P., Van Mourik, J.M., Van Reenen, G.B.A., Wallinga, J. \& Van der Plicht, J., 2010. Palaeoecological study of a Weichselian wetland site in the Netherlands suggests a link with Dansgaard-0eschger climate oscillations. Netherlands Journal of Geosciences 89: 187-201.

Van Strydonck, M., Nelson, D.E., Crombé, P., Bronk Ramsey, C., Scott, E.M., Van der Plicht, J. \& Hedges, R.E.M., 1999. What's in a ${ }^{14} \mathrm{C}$ date. In: J. Evin, C. Oberlin, J.P. Daugas and J.F. Salles (eds): Radiocarbon and Archaeology: Proceedings of the $3^{\text {rd }}$ International Symposium (Lyon): 433-440.

Wohlfarth, B., Skog, G., Possnert, G., \& Holmquist, B., 1998. Pitfalls in the AMS radiocarbon dating of terrestrial macrofossils. Journal of Quaternary Science 13: 137-145. 